\title{
PENGARUH WADAH MEMASAK YANG BERBEDA TERHADAP SIFAT FISIKO- KIMIA DAGING AYAM MASAK BUMBU RINTEK WUUK (RW)
}

\author{
Sri Hardiastuti Yusuf, John E.G. Rompis, Meilani R. Tinangon, E.H.B. Sondakh
}

Fakultas Peternakan, Universitas Sam Ratulangi Manado, 95115.

\begin{abstract}
ABSTRAK
Penelitian ini bertujuan untuk mengetahui pengaruh metode memasak dengan wadah yang berbeda terhadap sifat fisiko-kimia $(\mathrm{pH}$, daya mengikat air, dan susuk masak) daging ayam masak bumbu RW. Penelitian dilakukan dengan menggunakan Rancangan Acak Lengkap (RAL) melalui tiga perlakuan wadah (bambu, belanga tanah dan wajan) dengan menggunakan bumbu RW. Untuk sifat fisiko-kimia dianalisa di Laboratorium Teknologi Hasil Ternak. Analisis data menggunakan Analysis of Variance (ANOVA). Hasil dari penelitian ini menunjukan bahwa wadah memasak yang berbeda tidak mempengaruhi sifat fisikokimia daging ayam masak bumbu RW. Kesimpulan bahwa Memasak menggunakan wadah bambu, belanga tanah dan wajan tidak memberikan perubahan terhadap pH, DMA dan susut masak pada masakan ayam bumbu RW.
\end{abstract}

Kata kunci: Wadah Pemasakan, Bumbu RW, Sifat Fisiko-kimia

\section{ABSTRACT}

THE INFLUENCES OF DIFFERENT COOKING POT ON THE PHYSIC-CHEMICAL PROPERTIES OF THE TRADITIONAL "RINTEK WUUK

\footnotetext{
*Kosepondensi (corresponding author)
}

Email: jegronne@yahoo.co.id
(RW)" SEASONING CHICKEN. This research was done to evaluate the influence of cooking methods with different containers on physic-chemical properties ( $\mathrm{pH}$, water holding capacity, and cooking losses) of chicken meat seasoning traditional "rintek wuuk (RW)". The research was conducted using complete random draft (CRD) through three container treatment (bamboo, ground and frying pan) using RW traditional seasoning. The physic-chemical properties were analyzed in animal science technology laboratory. Data analysis used analysis of variance (ANOVA). Results of this study showed that different cooking containers did not affect the physic-chemical properties of seasoning RW chicken meat. These results can be concluded that the use of different containers did not give a real influence on the physic-chemical properties of the seasoning RW chicken meat.

Keywords: Chicken meat, cooking container, RW seasoning, Physic-chemical properties.

\section{PENDAHULUAN}

$$
\text { Masakan Indonesia memegang }
$$
peranan penting dalam budaya Nasional Indonesia, secara umum makanan-makanan Indonesia memiliki cita rasa yang khas serta kaya akan bumbu yang berasal dari rempah-rempah yang berkualitas. Tujuan memasak adalah menyatukan bahan, 
memperbaiki warna, menonaktifkan mikroba serta membuat produk siap dikonsumsi (Lumbong et al., 2017).

Kuliner tradisional Manado sangat beragam, ini sejalan dengan identitas masyarakatnya yang multi budaya. Sama seperti daerah lain, bahan dasar setiap masakan bervariasi dan terdiri dari berbagai macam bumbu dan rempah. Adapun salah satu masakan Manado yang kaya akan bumbu adalah masakan bumbu RW yang merupakan masakan khas dari Minahasa.

Rintek wuuk atau biasa disingkat RW dalam bahasa daerah Tanah Minahasa berarti bulu (rambut) halus. Pada awalnya RW terbuat dari daging anjing yang dimasak dengan aneka bumbu khas Tanah Minahasa, namun bumbu RW ini dapat juga diaplikasikan pada masakan daging ayam, bebek dan daging lainnya.

Daging ayam yang dibuat masakan menggunakan beberapa bumbu dapur tradisional (rempah). Bumbu dapur adalah campuran rempah-rempah yang digunakan sebagai penyedap. Pemberian bumbu pada masakan tradisional selain dimaksudkan untuk membangkitkan selera makan dan memberikan cita rasa yang khas pada suatu masakan, tenyata memiliki manfaat yang belum banyak diketahui oleh sebagian orang, yaitu bumbu juga berfungsi sebagai antioksidan, bahan pengawet alami dan dapat mencegah beberapa jenis penyakit.
Dalam memasak suatu bahan pangan mentah menjadi suatu masakan pada umumnya menggunakan beberapa wadah pemasakan. Selain bumbu, cara memasak makanan tradisional Minahasa pun berbeda-beda. Ada yang memasak menggunakan wadah bambu, wajan dan belanga tanah dengan sumber panas berasal dari kayu bakar. (Rompis dan Komansilan, 2014).

Wajan merupakan wadah memasak yang paling umum digunakan oleh masyarakat, karena penggunaan wajan yang praktis dan memiliki kemampuan tinggi dalam menghantarkan panas, namun penggunaan panas yang tidak terkontrol dalam proses pemasakan dapat mempengaruhi nilai gizi bahan pangan, yang disebabkan oleh kandungan logam dalam wajan tersebut, sehingga dibuatlah alternatif lain yaitu memasak menggunakan wadah bambu dan belanga tanah, kerena menggunakan wadah bambu bisa memberikan rasa dan aroma yang khas pada makanan, sedangkan memasak menggunakan wadah belanga tanah dapat mempertahankan sebagian nutrisi yang ada pada makanan.

Pemasakan menggunakan wadah yang berbeda ini diharapkan dapat memberi informasi mengenai sifat fisiko-kimia masakan tradisional daging ayam masak bumbu RW ditinjau dari wadah pemasakan yang berbeda, serta membuka wawasan 
bagi perkembangan makanan tradisional Minahasa dalam hubungannya dengan pengetahuan di bidang teknologi hasil ternak.

Tujuan penelitian ini dilakukan untuk mengetahui pengaruh metode memasak dengan wadah yang berbeda terhadap sifat fisiko-kimia yang terdiri dari $\mathrm{pH}$, daya mengikat air, dan susuk masak daging ayam masak bumbu RW.

\section{MATERI DAN METODE PENELITIAN}

\section{Bahan penelitian}

Bahan-bahan yang digunakan dalam penelitian ini terdiri dari $6 \mathrm{~kg}$ daging ayam broiler, 11 lembar daun pandan $( \pm 29$ g), 9 lembar daun kunyit ( \pm 72 g), 30 lembar daun jeruk $( \pm 18 \mathrm{~g}), 1$ ikat daun kemangi $( \pm 158 \mathrm{~g}), 12$ batang sereh $( \pm 162 \mathrm{~g}), 200 \mathrm{~g}$ cabe rawit, 24 biji bawang putih ( $\pm 77 \mathrm{~g}), 20$ butir bawang merah $( \pm 136 \mathrm{~g}), 13$ potong jahe $( \pm 64 \mathrm{~g}), 3$ ruas lengkuas $( \pm 88 \mathrm{~g})$, garam secukupnya, dan minyak kelapa 250 $\mathrm{mL}$.

\section{Peralatan Penelitian}

Peralatan yang digunakan dalam penelitian ini adalah bambu panjang $60 \mathrm{~cm}$ dan diameter $10 \mathrm{~cm}$, belanga tanah diameter $15 \mathrm{~cm}$ dan tinggi $13 \mathrm{~cm}$, wajan diameter $30 \mathrm{~cm}$, sendok, anglo (tungku), baskom, cobekan, thermometer bimetal, $\mathrm{pH}$ meter, pisau, talenan, kayu bakar, kertas Whattman 42, timbangan, 2 flat kaca dan beban $35 \mathrm{~kg}$.

\section{Metode Penelitian}

Penelitian ini dilaksanakan melalui suatu percobaan dengan menggunakan rancangan acak lengkap terdiri dari 3 perlakuan dan 6 ulangan. Susunan perlakuan dalam percobaan ini adalah:

R1: Wadah bambu

R2: Wadah belanga tanah

R3: Wajan

\section{Prosedur pembuatan ayam bumbu RW}

\section{Persiapan daging ayam}

Daging ayam dicuci bersih kemudian dipotong-potong dengan ukuran yang sama. Setelah dipotong lalu ditimbang $2 \mathrm{~kg}$ untuk setiap perlakuan.

\section{Persiapan bumbu}

Bumbu-bumbu yang akan digunakan dicuci bersih. Bawang putih, bawang merah, jahe, cabe rawit, lengkuas, sereh dan pala dihaluskan. Kemudian daun bawang, daun jeruk, daun kemangi, daun kunyit, dan daun pandan diiris halus.

\section{Pelaksanaan pemasakan}

Api yang digunakan sebagai sumber panas disiapkan, Bumbu yang telah dihaluskan dicampurkan secara merata pada daging. Daging ayam yang dicampurkan dengan bumbu dimasukkan 
ke dalam wadah bambu, belanga tahan dan wajan. Masing-masing wadah diisi $2 \mathrm{~kg}$ daging ayam. Kemudian pada bagian atas wadah bambu disumbat dengan menggunakan daun pisang sedangkan pada belanga tanah dan wajan ditutup dengan menggunakan penutupnya masing-masing. Selama proses memasak diusahakan agar panas yang diperoleh dari pembakaran kayu bakar selalu merata dan konstan. Dalam penelitian ini suhu wadah yang digunakan yaitu $71-73^{\circ} \mathrm{C}$ dan suhu api yaitu $85^{\circ} \mathrm{C}$. Setelah selesai masak, diangkat kemudian masukan kedalam wadah baskom yang telah disiapkan, kemudian didinginkan selama kurang lebih 10 menit dan dilanjutkan dengan pengujian sifat fisiko-kimia daging ayam masak bumbu RW.

\section{Prosedur pengukuran variabel pH}

Sampel ditimbang sebanyak 10 gram kemudian dihaluskan dan ditambahkan 20 $\mathrm{ml}$ aquades. Alat $\mathrm{pH}$ meter dikalibrasikan dahulu dengan menggunakan standard $\mathrm{pH}$ netral lalu dikeringkan dengan tissue kemudian elektroda dimasukan ke dalam sampel dan dibaca nilai $\mathrm{pH}$ yang tertera pada layar display alat pH meter (Soeparno, 2005).

\section{Daya mengikat air}

Nilai DMA dapat ditentukan dengan metode Hamm sesuai petunjuk (Soeparno
2005). Pertama-tama meletakkan sampel sebanyak 0,3 $\mathrm{g}$ di atas kertas saring Whatman 42 dan kemudian meletakkan diantara 2 plat kaca yang diberi beban $35 \mathrm{~kg}$ selama 5 menit. Menandai dan menggambar luasan area basah disekeliling kertas saring pada kertas grafik dengan pensil dan dari gambar tersebut diperoleh area basah. Kandungan air sampel (pada area basah) dapat di ukur dengan menggunakan rumus:

$$
\begin{aligned}
& \text { Area basah }=\text { LL-LD } \\
& \text { mgH2O }=\frac{\text { area basah }\left(\mathrm{cm}^{2}\right)}{0,0948}-8,0 \\
& \% \text { Kadar air }=\frac{\mathrm{W} 1-\mathrm{W} 2}{\mathrm{~W} 1} \times 100 \\
& \% \text { Kadar air bebas }=\frac{\mathrm{mgH} 20}{300 \mathrm{mg}} \times 100 \\
& \text { DMA }=\% \text { KA total }-\% \text { KA bebas }
\end{aligned}
$$

Keterangan :

LL : lingkar luar

LD : lingkar dalam

W1 : berat sampel awal

W2 : berat sampel akhir

KA : kadar air

\section{Susut Masak}

Susut masak merupakan indikator nilai nutrisi daging yang berhubungan dengan kadar air daging, yaitu banyaknya air yang terikat di dalam dan diantara otot. Pengujian susut masak dilakukan dengan memotong daging dengan potongan yang seragam lalu daging ditimbang. Kemudian daging dimasak selama 45 menit. Daging 
kemudian ditimbang lagi dan diukur susut masak dengan rumus :

$$
\% \text { Susut Masak }=\frac{\mathrm{a}-\mathrm{b}}{\mathrm{a}} \times 100
$$

Keterangan :

a : berat awal

$\mathrm{b}$ : berat akhir

\section{HASIL DAN PEMBAHASAN}

\section{Pengaruh Perlakuan Terhadap pH Daging Ayam bumbu RW}

Hasil pengamatan nilai $\mathrm{pH}$ daging ayam bumbu RW yang tercantum pada Tabel 1 memperlihatkan bahwa rataan tertinggi terdapat pada wadah bambu dengan skor 6,13 kemudian diikuti oleh wadah belanga tanah dengan skor 6,12 dan yang terendah terdapat pada wadah wajan dengan skor 6,07.

Berdasarkan hasil analisis sidik ragam menunjukan bahwa penggunaan wadah yang berbeda tidak memberikan perbedaan yang nyata $(\mathrm{P}>0,05)$ terhadap nilai $\mathrm{pH}$ daging ayam bumbu $\mathrm{RW}$.

Faktor utama yang mempengaruhi derajat keasaman $(\mathrm{pH})$ yaitu faktor sebelum dan setelah pemotongan. Menurut Dewayani (2015) bahwa proses pemotongan dapat berpengaruh terhadap kualitas daging yang dihasilkan, karena setelah ternak dipotong akan terjadi proses glikolisis yang dapat mempengaruhi nilai $\mathrm{pH}$. Semakin lama waktu postmortem akan terjadi penurunan $\mathrm{pH}$ yang semakin rendah akibat proses konversi otot menjadi daging pada jarak waktu postmortem tertentu.

Nilai $\mathrm{pH}$ pada masing-masing wadah yang tercantum pada Tabel 1 memiliki variasi yang tidak jauh berbeda karena daging ayam broiler yang digunakan adalah daging segar dengan waktu 4 jam setelah pemotongan kemudian diolah menjadi ayam bumbu RW. Menurut Suradi (2008) dalam Hajrawati et al. (2016) menyatakan bahwa daging ayam broiler memiliki pH 6,31 pada saat segera setelah pemotongan, kemudian mengalami penurunan dengan jangka waktu 4 jam setelah pemotongan dengan $\mathrm{pH} \quad 6,16$. Sehingga faktor-faktor diatas tidak berpengaruh terhadap nilai $\mathrm{pH}$ daging, karena daging ayam yang digunakan adalah daging ayam broiler dengan umur yang sama, cara pemotongannya sama, suhu api dan suhu wadah pemasakannya yang sama, hanya berbeda pada perlakuannya saja sehingga membuat nilai $\mathrm{pH}$ tidak berbeda nyata.

\section{Pengaruh Perlakuan Terhadap DMA Daging Ayam bumbu RW}

Hasil pengamatan daya mengikat air daging ayam masak bumbu RW dari masing-masing perlakuan disajikan pada Tabel 1. Hasil pengamatan untuk daya mengikat air (DMA) daging ayam bumbu 
Tabel 1. Nilai rataan pH, Daya Mengikat Air, dan Susut Masak.

\begin{tabular}{lccc}
\hline \multirow{2}{*}{ Variabel } & \multicolumn{3}{c}{ Perlakuan } \\
\cline { 2 - 4 } \multicolumn{1}{c}{ BH } & 6,13 & Wajan & Belanga Tanah \\
\hline Daya Mengikat Air & 58,15 & 6,07 & 6,12 \\
Susut Masak & 34,33 & 58,09 & 58,11 \\
\hline
\end{tabular}

RW pada Tabel 1 memperlihatkan rataan tertinggi terdapat pada wadah bambu dengan skor 58,15 kemudian diikuti oleh wadah belanga tanah dengan skor 58,11 dan terendah terdapat pada wadah wajan dengan skor 58,09.

Berdasarkan hasil analisis sidik ragam menunjukan bahwa penggunaan wadah yang berbeda tidak memberikan perbedaan yang nyata $(\mathrm{P}>0,05)$ terhadap nilai daya mengikat air daging ayam bumbu RW.

Daya mengikat air oleh protein daging didefinisikan sebagai kemampuan daging untuk menahan air atau air yang ditambahkan selama ada pengaruh kekuatan, seperti pemotongan daging, pemanasan, penggilingan, dan tekanan (Soeparno, 2009). Daya mengikat air dapat dipengaruhi oleh bangsa, proses rigormortis, temperature, kelembaban, pelayuan, tipe dan lokasi otot, fungsi otot, pakan, lemak intramuskuler dan $\mathrm{pH}$ (Kuntoro et al., 2013). Daya mengikat air pada penelitian ini tidak berbeda nyata disebabkan oleh nilai $\mathrm{pH}$ daging yang tidak berbeda nyata untuk setiap perlakuan, pernyataan ini didukung oleh Lawrie (2003) menyatakan bahwa daya mengikat air daging sangat dipengaruhi oleh $\mathrm{pH}$, semakin tinggi $\mathrm{pH}$ daging semakin tinggi daya mengikat air.

\section{Pengaruh Perlakuan Terhadap Susut Masak Daging Ayam Bumbu RW}

Hasil pengamatan untuk susut masak daging ayam bumbu RW pada Tabel 1 memperlihatkan rataan tertinggi terdapat pada wadah wajan dengan skor 34,83 kemudian diikuti oleh wadah belanga tanah dengan skor 34,50 dan terendah terdapat pada wadah bambu dengan skor 34,33.

Berdasarkan hasil analisis sidik ragam menunjukan bahwa penggunaan wadah yang berbeda tidak memberikan perbedaan yang nyata $(\mathrm{P}>0,05)$ terhadap nilai susut masak daging ayam bumbu RW.

Besarnya susut masak dipengaruhi oleh banyaknya air yang keluar dari daging, umur simpan daging, degradasi protein dan kemampuan daging untuk mengikat air (Shanks et al., 2002). Menurut Soeparno, 2005 bahwa daging dengan jumlah susut masak rendah mempunyai kualitas lebih 
baik karena kehilangan nutrisi lebih sedikit saat perebusan.

Nilai susut masak dapat dipengaruhi oleh daya mengikat air, sehingga nilai susut masak dari wadah bambu, belanga tanah dan wajan tidak memberikan perbedaan yang nyata karena nilai daya mengikat air dari wadah bambu, belanga tanah dan wajan juga tidak memberikan perbedaan yang nyata. Hal ini sesuai dengan pendapat Prayitno et al. (2010) dalam Wowor et al. (2014), semakin kecil persentase susut masak berarti semakin sedikit air yang hilang dan nutrient yang larut dalam air. Begitu juga sebaliknya semakin besar persentase susut masak maka semakin banyak air yang hilang dan nutrient yang larut dalam air.

\section{KESIMPULAN}

Memasak menggunakan wadah bambu, belanga tanah, wajan tidak memberikan perubahan terhadap $\mathrm{pH}$, DMA dan susut masak pada masakan ayam bumbu RW

\section{DAFTAR PUSTAKA}

Dewayani, R. E., H. Natsir, dan O. Sjofjan. 2015. Pengaruh penggunaan onggok dan ampas tahu terfermentasi Mix Culture Aspergillus Niger dan Rhizopus Oligosporus sebagai pengganti jagung dalam pakan terhadap kualitas fisik daging ayam pedaging. Jurnal Ilmu dan Teknologi Hasil Ternak 10(1): 911

Hajrawati, F., M. Wahyuni dan I.I. Arief 2016. Kualitas fisik, mikrobiologis, dan organoleptik daging ayam broiler pada pasar tradisional di Bogor. Jurnal Ilmu Produksi dan Teknologi Hasil Peternakan 4(3): 386-389.

Kuntoro, B., R.R.A. Maheswari., H. Nuraini. 2013. Mutu fisik dan mikrobiologi daging sapi asal rumah potong hewan (RPH) Pekanbaru. Jurnal Peternakan 10(1).

Lawrie, R.A. 2003. Meat science. 6th Edit. Terjemahan. A. Parakasi dan A. Yudha. Penerbit Universitas Indonesia, Jakarta.

Lumbong, R., R. M. Tinangon, M. D. Rotinsulu, dan J. A. D. Kalele. 2017. Sifat organoleptik burger ayam dengan metode memasak yang berbeda. Jurnal Zootek $37(2): 252-258$.

Rompis, J.E.G., dan S. Komansilan. 2014. Efektivitas cara pemasakan terhadap karakteristik fisik masakan daging babi hutan. Jurnal Zootek 34(2): $65-70$

Rosyidi, D., A. Susilo, dan I. Wiretno. 2010. Pengaruh bangsa sapi terhadap kualitas fisik dan kimiawi daging. Jurnal Ilmu dan Teknologi Hasil Ternak 5(1): 11-17

Shanks, B. C., D.M.Wolf, R.J. Maddock. 2002. Technical note: the effect of freezing on warner bratzler shear force values of beef longissimus steak across several postmortem aging periods. J. Animal Science 80: 2122-2125. 
Soeparno. 2005. Ilmu dan teknologi daging, cetakan keempat. Gadjah Mada University Press.Yogyakarta.

Soeparno. 2009. Ilmu dan teknologi daging. Cetakan kelima. UGM Press. Yogyakarta.

Wowor, A. K. Y., T.A. Ransaleleh, M. Tamasoleng, dan S. Komansilan. 2014. Lama penyimpanan pada suhu dingin daging broiler yang diberi air perasan jeruk kasturi (Citrus Madurensis Lour.). Jurnal Zootek 34(2): 148 - 158. 